\title{
A survey of cancer and occupation in young and middle aged men. I Cancers of the respiratory tract
}

\author{
D COGGON, B PANNETT, C OSMOND, AND E D ACHESON
}

From the MRC Environmental Epidemiology Unit, University of Southampton, Southampton General Hospital, Southampton SO9 $4 X Y, U K$

ABSTRACT In a search for clues to previously unrecognised industrial carcinogens the occupational and smoking histories of young and middle aged men with different types of cancer were compared. The study population comprised men aged 18-54 and resident in the counties of Cleveland, Humberside, and Cheshire (including the Wirral). From hospital and cancer registration records 2942 members of the study population in whom cancers were diagnosed during the period 1975-80 were identified retrospectively. The occupational and smoking histories of these patients were sought by a postal questionnaire addressed either to the patients themselves or, if they had died, to their next of kin. The overall response rate to the questionnaire was $52 \cdot 1 \%$. Additionally, limited occupational information was obtained for $89 \%$ of cases from their hospital notes. Analysis of these data suggests that no serious bias arose as a consequence of the incomplete response to the questionnaire. This paper concentrates on the results for cancers of the respiratory tract and mesothelioma. Mesothelioma was found to cluster in laggers, electricians, and shipyard workers, and nasal carcinoma in woodworkers. Carcinomas of the larynx and of the bronchus were examined by formal statistical techniques, each being compared with a control group made up of all other cancers combined. Several interesting occupational and industrial associations were shown, in particular, an excess of bronchial carcinoma in the leather industry $(R R=2 \cdot 6, C I 1 \cdot 2-6 \cdot 0)$, in building labourers $(R R=$ $1 \cdot 7, \mathrm{CI} 1 \cdot 0-2 \cdot 9)$ and other construction workers $(\mathrm{RR}=1 \cdot 8, \mathrm{CI} 1 \cdot 0-3 \cdot 0)$, in bakers and pastry cooks $(R R=3 \cdot 6, C I 1 \cdot 3-10 \cdot 4)$, and in cooks $(R R=2 \cdot 5, C I 1 \cdot 2-5 \cdot 1)$. In addition, a small cluster of lung tumours was observed in men who had worked as dental mechanics.

Most of the known occupational causes of cancer were discovered through the alertness of observant clinicians. It is significant, however, that two hazards - the risk of bladder cancer in rubber workers and of nasal carcinoma in boot and shoe manufacturers-first came to light incidentally in the course of epidemiological investigations. ${ }^{1}$ In both instances the choice of the population under study was fortuitous. Similar surveys carried out in other geographical areas would not have shown the hazards. Such chance findings suggest that systematic epidemiological searches might disclose further, as yet unrecognised, occupational carcinogens.

To date, attempts to screen populations for occupational risks of cancer have met with only limited success. Several promising clues have been generated

Accepted 9 September 1985 but few have been adequately followed up. Possibly the sensitivity of screening studies could be improved by concentrating on cancers occurring at young ages. Such an approach has several potential advantages. Diagnostic data should be more accurate since clinical investigation is generally more thorough in young people. Occupational information should also be more reliable because the employment histories of young people go back less far in time. In addition, it appears that for several known industrial carcinogens-for example, chromates ${ }^{2}$ and bischloromethyl ether ${ }^{3}$ - the relative risk of cancer is highest and therefore most readily detectable at $\mathrm{\omega}$ young ages. This effect will if anything be exaggerated for recently introduced carcinogens to which cumulative exposure is similar in all age groups (if a hazard has been present for many years older workers will tend to have the greatest cumulative exposure).

We describe here a survey in which we have compared the occupational histories of young and middle 


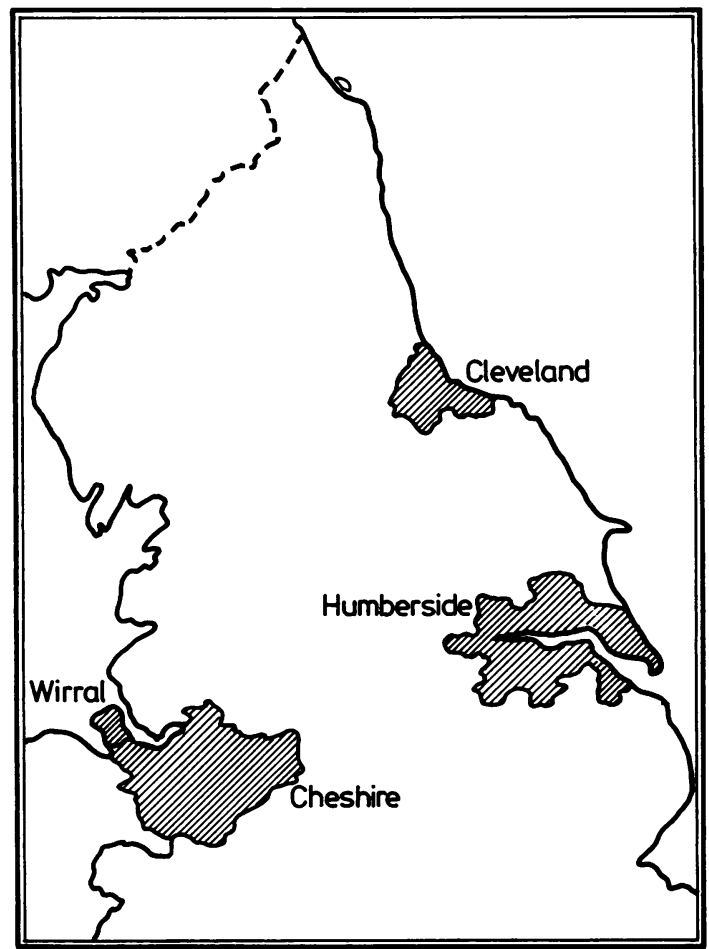

Fig 1 Map showing boundaries of study area.

aged men with different types of cancer. Results are presented for tumours of the respiratory tract. The findings for cancers at other sites are described elsewhere. ${ }^{4}$

\section{Method}

The study population comprised men aged $18-54$ and resident in the areas shown in fig 1 . These correspond roughly to the counties of Cleveland, Humberside, and Cheshire, together with the Wirral district of Merseyside. The main industries of the study area are chemical production (especially general chemicals, soaps and detergents, and petrochemicals), metal manufacture, vehicle construction, and mechanical engineering.

We attempted to identify retrospectively all cancers (other than basal cell carcinoma of the skin) diagnosed in the study population during the six years 1975-80. In Cleveland and Humberside this was done by searching the pathology records of local hospitals. Necropsy, cytology, and bone marrow reports were examined as well as histopathology files. Further information about the patients was then sought from their hospital case notes, including any record of occupation. (A limited occupational history was usually available from hospital activity analysis forms or occasionally from death certificates.) Care was taken to exclude recurrent tumours first diagnosed before 1975. In Cheshire and the Wirral it would have been impractical to ascertain cases through pathology departments because a substantial proportion of patients are referred out of the area to the teaching hospitals of Liverpool and Manchester for diagnosis and treatment. Instead, therefore, cases were ascertained through the Mersey Regional Cancer Registry (approval having first been obtained from the local ethical committees). If necessary the information from the registry was supplemented by reviewing hospital case notes.

When we had identified a patient we wrote to his general practitioner asking him to confirm whether or not the patient was still alive, and requesting his permission to send a postal questionnaire about occupation and smoking either to the patient himself or, if he had died, to his next of kin. The occupational questionnaire asked for details of each job held by the patient from the time he left school, including the dates of starting and finishing, the title of the occupation, and either the name and address of the place of work or alternatively the industry in which the occupation was carried out. General practitioners who did not respond to our initial letter were sent reminders or contacted by telephone, if necessary several times. Patients and relatives who failed to respond to the questionnaire were sent a single reminder after two or three months. A few patients had moved house and changed their general practitioner since their last attendance at hospital. When possible these men were traced through the National Health Service Central Register and local family practitioner committees, and then contacted through their new doctors.

Two methods were used to explore the relation between cancer and occupation. The more common tumours (those for which at least 20 occupational histories were obtained in response to the postal questionnaire) were examined by formal statistical techniques. Each individual diagnostic category was compared with all other cancers combined. Jobs reported in the questionnaire were coded using the Registrar General's 1966 classification of occupations ${ }^{5}$ and 1968 classification of industries, ${ }^{6}$ and risks were calculated for men who had ever worked in an occupation or industry before diagnosis relative to that of men never so employed. Allowance was made for age $(18-34,35-44,45-49$, or 50-54), county of residence (Cheshire and the Wirral, Cleveland, or Humberside), the source of the history (patient or relative), and smoking (non-smoker, ex-smoker, light smoker, 
or heavy smoker*); and Mantel-Haenszel summary estimates of relative risk (RR) were derived with approximate $95 \%$ confidence intervals $(\mathrm{CI}){ }^{7}$

Tumours that occurred less often were studied simply by inspecting all the available occupational data about patients with the disease (information obtained both from questionnaires and from hospital records) in a search for any common features.

\section{Results}

The search of hospital and cancer registration records showed 2942 patients eligible for inclusion in the study. The data in table 1 show the frequency with which different types of cancer occurred and the response rates that were obtained according to whether subjects were alive or dead at the time of the survey. The overall response rate was $52 \cdot 1 \%$. The main reasons for the incomplete response were advice from the general practitioner not to contact the patient or his family (11.0\% of all cases), difficulty in tracing informants, particularly relatives of those who had died $(6.4 \%)$, and failure of informants to reply when sent a questionnaire $(18.5 \%)$. The process of data collection is summarised in fig 2.

We concentrate here on results for cancers of the respiratory tract and mesothelioma (pleural and peritoneal mesotheliomas were analysed together). Car-

*The distinction between light and heavy smokers depended on the duration of smoking and the amount smoked. cinoma of the nose, nasopharyngeal carcinoma, and mesothelioma all occurred too infrequently for formal statistical analysis. Inspection of occupational histories, however, showed that three of the seven patients with nasal carcinoma had been woodworkers (two in the furniture industry and one building river boats); and that of 14 patients with mesothelioma, three had been electricians, three had worked in shipyards (including one of the electricians), and three had been laggers. There were no occupational clusters among the six patients with carcinoma of the $\vec{\circ}$ nasopharynx.

Carcinomas of the larynx and the bronchus were examined statistically. Tables 2 and 3 show the associations between these tumours and the industrial and occupational orders defined by the Registrar General. The risk of laryngeal carcinoma was significantly raised in painters and decorators $(R R=3.4, C I$ 1.3-9.0) and among men who had worked in the manufacture of metals $(R R=2 \cdot 5, \mathrm{CI} 1 \cdot 2-5 \cdot 3)$. The latter association was due largely to an excess of the tumour in the iron and steel industry, but within the industry no single occupation stood out as being particularly at risk.

Carcinoma of the bronchus was associated with the construction industry $(R R=1.4, C I 1.0-1.9)$ and with the manufacture of leather, leather goods, and fur $(R R=2 \cdot 6$, CI 1.2-6.0). Seven of the eight cases from the leather industry had worked in tanneriesfive had been production workers, one a clerk, and the precise occupation of the last was unknown. Of

Table 1 Distribution of cancers in study sample and response rates

\begin{tabular}{|c|c|c|c|c|c|c|}
\hline \multirow[t]{2}{*}{ Cancer* } & \multicolumn{2}{|l|}{ Alive } & \multicolumn{2}{|l|}{ Dead } & \multicolumn{2}{|l|}{ Total } \\
\hline & No of cases & $\begin{array}{l}\text { Response rate } \\
(\%)\end{array}$ & No of cases & $\begin{array}{l}\text { Response rate } \\
(\%)\end{array}$ & No of cases & $\begin{array}{l}\text { Response rate } \\
(\%)\end{array}$ \\
\hline $\begin{array}{l}\text { Carcinoma of bronchus } \\
\text { Carcinoma of bladder and renal pelvis } \\
\text { Carcinoma of stomach } \\
\text { Carcinoma of colon } \\
\text { Carcinoma of rectum } \\
\text { Testicular cancer } \\
\text { Hodgkins disease } \\
\text { Cancer of brain } \\
\text { Non-Hodgkins lymphoma } \\
\text { Carcinoma of renal parenchyma } \\
\text { Carcinoma of oesophagus } \\
\text { Malignant melanoma } \\
\text { Carcinoma of pancreas } \\
\text { Carcinoma of oral cavity } \\
\text { Carcinoma of skin } \\
\text { Carcinoma of larynx } \\
\text { Soft tissue sarcoma } \\
\text { Carcinoma of prostate } \\
\text { Other } \\
\text { Total }\end{array}$ & $\begin{array}{r}63 \\
194 \\
26 \\
59 \\
67 \\
121 \\
74 \\
24 \\
44 \\
21 \\
5 \\
36 \\
1 \\
31 \\
51 \\
33 \\
29 \\
13 \\
138 \\
1030\end{array}$ & $\begin{array}{r}65 \cdot 1 \\
69 \cdot 6 \\
53 \cdot 8 \\
62 \cdot 7 \\
71 \cdot 6 \\
60 \cdot 3 \\
71 \cdot 6 \\
54 \cdot 2 \\
72 \cdot 7 \\
61 \cdot 9 \\
40 \cdot 0 \\
63 \cdot 9 \\
0 \cdot 0 \\
67 \cdot 7 \\
62 \cdot 7 \\
60 \cdot 6 \\
62 \cdot 1 \\
69 \cdot 2 \\
61 \cdot 6 \\
65 \cdot 0\end{array}$ & $\begin{array}{r}675 \\
78 \\
172 \\
117 \\
100 \\
39 \\
45 \\
73 \\
53 \\
54 \\
63 \\
28 \\
61 \\
29 \\
8 \\
24 \\
25 \\
22 \\
246 \\
1912\end{array}$ & $\begin{array}{l}40 \cdot 1 \\
56 \cdot 4 \\
45 \cdot 9 \\
48 \cdot 7 \\
51 \cdot 0 \\
46 \cdot 2 \\
37 \cdot 8 \\
45 \cdot 2 \\
56 \cdot 6 \\
48 \cdot 1 \\
41 \cdot 3 \\
42.9 \\
41 \cdot 0 \\
44 \cdot 8 \\
37 \cdot 5 \\
50 \cdot 0 \\
60 \cdot 0 \\
36.4 \\
50 \cdot 4 \\
45 \cdot 2\end{array}$ & $\begin{array}{r}738 \\
272 \\
198 \\
176 \\
167 \\
160 \\
119 \\
97 \\
97 \\
75 \\
68 \\
64 \\
62 \\
60 \\
59 \\
57 \\
54 \\
35 \\
384 \\
2942\end{array}$ & $\begin{array}{l}42 \cdot 3 \\
65 \cdot 8 \\
47 \cdot 0 \\
53.4 \\
59 \cdot 3 \\
56.9 \\
58 \cdot 8 \\
47.4 \\
63.9 \\
52.0 \\
41 \cdot 2 \\
54.7 \\
40.3 \\
56 \cdot 7 \\
59 \cdot 3 \\
56.1 \\
61 \cdot 1 \\
48.6 \\
54.4 \\
52.1\end{array}$ \\
\hline \multicolumn{7}{|c|}{$\begin{array}{l}\text { *If a patient developed more than one cancer during the period of study only the first cancer to be diagnosed has been counted. } \\
\text { +Includes papilloma of the bladder. } \\
\text { †Includes sarcomas of specific organs-for instance, leiomyosarcoma of stomach. }\end{array}$} \\
\hline
\end{tabular}




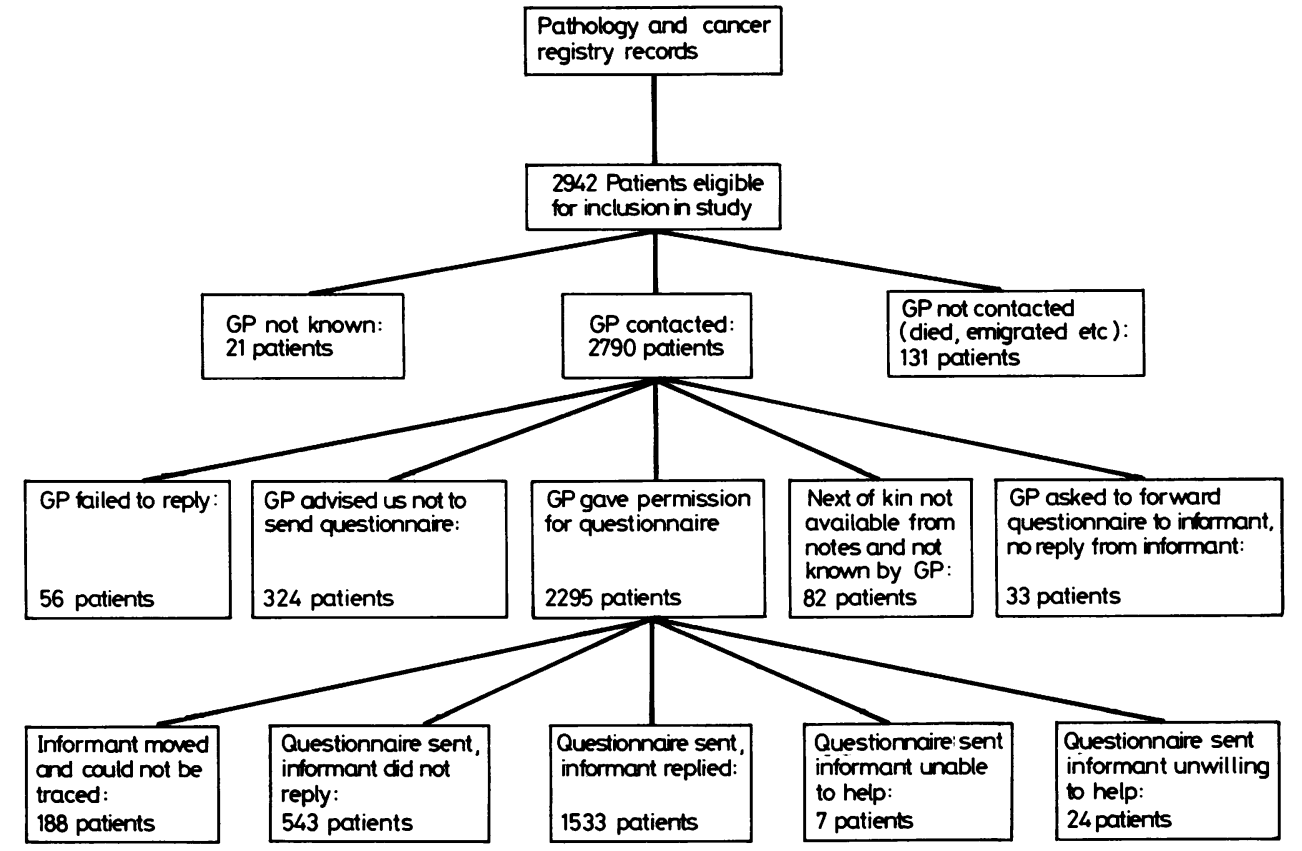

Fig 2 Summary of data collection and reasons for incomplete response.

the occupational orders, woodworkers $(\mathbf{R R}=1 \cdot 7, \mathbf{C I}$ $1 \cdot 0-3 \cdot 0)$ and gas, coke, and chemical makers ( $R R=$ $1 \cdot 8$, CI 1.1-2.9) were the most strongly associated with bronchial carcinoma. Four cases had worked as furnacemen in the production of coal gas and coke $(R R=5 \cdot 2)$, but otherwise the excess among chemical process workers was not concentrated in any one branch of the industry. Examination of more specific occupational categories (occupational units in the Registrar General's classification) showed additional associations with bakers and pastry cooks $(R R=3 \cdot 6$, CI 1.3-10.4), cooks (RR $=2 \cdot 5, \mathrm{CI} 1 \cdot 2-5 \cdot 1)$, labourers in construction ( $R R=1 \cdot 7, \mathrm{CI} 1 \cdot 0-2 \cdot 9)$, and construction workers not elsewhere classified $(R R=1.8, C I$ $1 \cdot 0-3 \cdot 0)$. The 28 cases classed as construction workers not elsewhere classified included six insulation workers and two men who had worked with asbestos roofing. Three patients with lung cancer had been dental mechanics (the only dental mechanics in the study sample).

\section{Discussion}

An advantage of this screening survey was the detail of the occupational data that were collected. Even the histories elicited from next of kin, although unlikely to be as complete as histories provided by the patients themselves, ${ }^{8}$ were more extensive than those used in the routine analyses of occupational mortality and cancer incidence published by the Office of Population Censuses and Surveys. ${ }^{910}$ The availability of data about smoking was a further asset. Restriction of the study to a limited geographical area with a few dominant local industries meant that cancers could usefully be examined even when information was only available for a few cases.

The low overall response rate was a potential source of bias. Nevertheless, examination of response rates in relation to the limited occupational data that were available from hospital and cancer registration records (a description of the most recent full time job was obtained for $89 \%$ of subjects) indicates that the variation in response by type of cancer was independent of occupation. It seems unlikely, therefore, that any major bias arose from the incomplete response.

Another possible source of error was the restriction of the analysis to comparisons between patients with different types of cancer. There is a danger that hazards which predispose to a wide range of tumours may have been missed. The advantage of confining attention to patients with cancer was that it made the investigation more efficient-since each subject served both as a case and control-and also reduced the likelihood of recall bias.

The analysis was based on all jobs held up to the time of diagnosis, and thus made no allowance for 
Table 2 Associations of laryngeal and bronchial carcinomas with industrial orders: relative risk and (in parentheses) the number of cases from the industry concerned

\begin{tabular}{|c|c|c|}
\hline Industrial order & Carcinoma of larynx & Carcinoma of bronchus \\
\hline $\begin{array}{l}\text { Agriculture, forestry, fishing } \\
\text { Mining and quarrying } \\
\text { Food, drink, and tobacco } \\
\text { Coal and petroleum products } \\
\text { Chemicals and allied industries } \\
\text { Metal manufacture } \\
\text { Mechanical engineering } \\
\text { Instrument engineering } \\
\text { Electrical engineering } \\
\text { Shipbuilding and marine engineering } \\
\text { Vehicles } \\
\text { Metal goods nec } \\
\text { Textiles } \\
\text { Leather, leather goods, and fur } \\
\text { Clothing and footwear } \\
\text { Bricks, pottery, glass, cement, etc } \\
\text { Timber, furniture, etc } \\
\text { Paper, printing, and publishing } \\
\text { Other manufacturing industries } \\
\text { Construction } \\
\text { Gas, electricity, and water } \\
\text { Transport and communication } \\
\text { Distributive trades } \\
\text { Insurance, banking, finance, and business services } \\
\text { Professional and scientific services } \\
\text { Miscellaneous services } \\
\text { Public administration and defence }\end{array}$ & $\begin{array}{l}0.8(3) \\
0.7(1) \\
0.8(4) \\
0.8(2) \\
2.1(10) \\
2.5(13) \\
1.3(6) \\
-(0) \\
1.2(2) \\
2.0(6) \\
0.6(3) \\
1.9(4) \\
0.7(1) \\
-2.3(1) \\
0.6(1) \\
0.6(1) \\
1.2(2) \\
-(0) \\
2.2(15) \\
0.6(1) \\
0.9(9) \\
0.8(8) \\
-(0) \\
-(0) \\
1.5(7) \\
0.7(18)\end{array}$ & $\begin{array}{l}0.7(32) \\
0.5(11) \\
1.2(51) \\
0.9(17) \\
1 \cdot 1(64) \\
1.0(72) \\
0.7(33) \\
1.8(4) \\
0 \cdot 6(10) \\
1 \cdot 1(35) \\
1.4(44) \\
1 \cdot 1(19) \\
0.9(10) \\
2.6(8) \\
0.8(3) \\
0.5(9) \\
1.6(17) \\
1.0(15) \\
0.8(7) \\
1.4(97) \\
1.1(16) \\
0.9(96) \\
0.9(73) \\
1.0(10) \\
0.4(17) \\
1.1(43) \\
0.9(204)\end{array}$ \\
\hline
\end{tabular}

nec $=$ Not elsewhere classified.

any latency in the onset of tumours. Reanalysis, excluding jobs which started within five years of diagnosis, however, had no important effect on the results.

Although the study included only a few patients with nasal carcinoma or mesothelioma, clues to the roles of wood dust and asbestos in their aetiology were apparent. Three of the seven patients with nasal cancer had been woodworkers and three of the 14 men with mesothelioma had worked as laggers-in both instances much higher proportions than would have been expected by chance. The relative risks associated with these carcinogens are high, and it is reas-

Table 3 Associations of laryngeal and bronchial carcinomas with occupational orders: relative risk and (in parentheses) the number of cases from the occupation concerned

\begin{tabular}{|c|c|c|}
\hline Occupational order & Carcinoma of larynx & Carcinoma of bronchus \\
\hline $\begin{array}{l}\text { Farmers, foresters, fishermen } \\
\text { Miners and quarrymen } \\
\text { Gas, coke, and chemical makers } \\
\text { Glass and ceramics makers } \\
\text { Furnace, forge, foundry, rolling mill workers } \\
\text { Electrical and electronic workers } \\
\text { Engineering and allied trades workers nec } \\
\text { Woodworkers } \\
\text { Leather workers } \\
\text { Textile workers } \\
\text { Clothing workers } \\
\text { Food, drink, and tobacco workers } \\
\text { Paper and printing workers } \\
\text { Makers of other products } \\
\text { Construction workers } \\
\text { Painters and decorators } \\
\text { Drivers of stationary engines, cranes, etc } \\
\text { Labourers nec } \\
\text { Transport and communication workers } \\
\text { Warehousemen, storekeepers, packers, bottlers } \\
\text { Clerical workers } \\
\text { Sales workers } \\
\text { Service, sport, and recreation workers } \\
\text { Administrators and managers } \\
\text { Professional, technical workers, artists } \\
\text { Armed forces (British and foreign) }\end{array}$ & $\begin{array}{l}0.8(3) \\
1.0(1) \\
0.3(1) \\
-(0) \\
1.3(3) \\
0.5(1) \\
1.5(16) \\
-(0) \\
1.6(1) \\
2 \cdot 4(1) \\
-(0) \\
0 \cdot 6(2) \\
0.9(1) \\
0.6(1) \\
1.6(6) \\
3.4(6) \\
0.5(2) \\
2.0(11) \\
1.0(11) \\
1.2(4) \\
0.1(1) \\
0.4(4) \\
1.2(5) \\
0.9(3) \\
0.4(2) \\
1.1(14)\end{array}$ & $\begin{array}{l}0.8(35) \\
0.7(8) \\
1.8(36) \\
-1(0) \\
1.6(22) \\
0.8(16) \\
0.9(102) \\
1.7(26) \\
2 \cdot 1(6) \\
0.3(1) \\
0.5(2) \\
1.3(30) \\
1.2(8) \\
1.7(15) \\
1.4(41) \\
1.3(20) \\
0.9(23) \\
1.3(73) \\
0.9(105) \\
1.1(26) \\
1.0(41) \\
0.9(56) \\
1.2(52) \\
0.5(14) \\
0.4(18) \\
1.1(153)\end{array}$ \\
\hline
\end{tabular}

nec $=$ Not elsewhere classified. 
suring that the screening method was sufficiently sensitive to detect their effects.

The analyses for laryngeal and bronchial carcinomas entailed over 100 case-control comparisons, and it follows that several chance associations could be expected to achieve conventional levels of statistical significance. Interpretation of the results depends not only on the risk estimates and their confidence limits but also on the specificity of associations within the broad occupational and industrial categories that were examined, the biological plausibility of the hazards suggested, and the weight of evidence from other epidemiological studies. Several of the associations that were found merit comment.

The increased risk of laryngeal cancer in painters raises suspicions of a hazard from the inhalation of solvent vapours. The association has not been a consistent finding in other studies, ${ }^{11}$ however, and in the OPCS 1971 decennial supplement on occupational mortality the standardised mortality ratio of painters and decorators for laryngeal cancer was only $76 .{ }^{9} \mathrm{De}$ tailed examination of the histories of our cases gave no indication of a special local factor which might account for the high incidence in painters, and it seems likely that the association occurred by chance.

By contrast, the raised risk of lung cancer among furnacemen employed in the manufacture of coal gas and coke is well established. ${ }^{1}$ The excess of the tumour among other chemical workers was not related to any one manufacturing process but exposure to asbestos may have been a contributing factor.

Asbestos exposure almost certainly underlies the high incidence of bronchial carcinoma found in construction workers, although other agents such as polycyclic aromatic hydrocarbons may also have had a role. A risk of lung cancer in construction workers has been reported in several other studies. ${ }^{91112}$

The epidemiological evidence for a hazard of lung cancer in leather workers is less convincing. Two analyses of occupational mortality have shown high death rates from lung tumours among tanners, ${ }^{913}$ but the association has not been consistently shown in other investigations, ${ }^{1114}$ and was not apparent in a recent cohort study of boot and shoe manufacturers. ${ }^{15}$

The two most interesting findings of the study were the small cluster of lung tumours in dental mechanics and the excess of lung cancer in bakers and cooks. The first association is difficult to evaluate because most epidemiological studies have not distinguished dental mechanics as a specific occupational category. It only became apparent in the present study when the detailed histories of cases from the occupational order "makers of other products" were reviewed. The cluster comprised only three cases and may have occurred by chance. Dental mechanics, however, are exposed to several potential hazards including solvents, fumes, dusts from abrasives, and asbestos paper, ${ }^{16}$ and an increased risk of lung cancer has been reported in two previous surveys. ${ }^{1718}$ In view of this further investigation is indicated.

A high incidence of bronchial carcinoma in cooks has been reported in several previous studies, ${ }^{91117-19}$ and the finding of a largely independent association with bakers and pastry cooks (two patients with lung cancer had been both cooks and bakers) adds weight to the suspicion of a hazard. Theoretical explanations for the risk include exposure to polycyclic aromatic hydrocarbons or nitrosamines in fumes. The histories of the cases do not implicate any specific type of cooking, and the fact that many of them last worked as cooks 20 or more years ago argues against the association being an effect of a recent innovation such as microwave ovens. Again, further research is indicated. Only by following up clues such as these will the value of hypothesis generating studies be established.

We thank the consultant pathologists who assisted us in the ascertainment of cases-especially Drs $\mathbf{J} \mathbf{M}$ Johnstone, D M Piercy, R E Potts, E W Walton, and $H$ McTaggart; the staff of the Mersey Regional Cancer Registry - in particular, Dr D N Edwards (consultant in charge) and Mrs S Gravestock (medical records officer); OPCS for their help in tracing patients who had moved; and all the general practitioners who cooperated in the survey.

\section{References}

${ }^{1}$ Doll $\mathrm{R}$. Pott and the prospects for prevention. $\mathrm{Br} J$ Cancer 1975;32:263-72.

2 Bidstrup PL, Case RAM. Carcinoma of the lung in workmen in the bichromates producing industry in Great Britain. Br J Ind Med 1956;13:260-4.

${ }^{3}$ Weiss W, Boucot KR. The respiratory effects of chloromethyl methyl ether. JAMA 1975;234:1139-42.

${ }^{4}$ Coggon D, Pannett B, Osmond C, Acheson ED. A survey of cancer and occupation in young and middle aged men. II Nonrespiratory cancers. $\mathrm{Br} J$ Ind $\mathrm{Med}$ (in press).

${ }^{5}$ General Register Office. Classification of occupations (1966). London: HMSO, 1966.

${ }^{6}$ Central Statistical Office. Standard industrial classification. London: HMSO, 1968.

${ }^{7}$ Breslow NE, Day NE. Statistical methods in cancer research. Vol 1. The analysis of case-control studies. Lyon: International Agency for Research on Cancer, 1980.

${ }^{8}$ Coggon D, Pippard EC, Acheson ED. The accuracy of occupational histories obtained from wives. $\mathrm{Br} J$ Ind Med 1985;42:563-4.

${ }^{9}$ Office of Population Censuses and Surveys. Occupational mortality 1970-72. Decennial supplement for England and Wales. London: HMSO, 1978. (Series DS No 1.)

${ }^{10}$ Office of Population Censuses and Surveys. Cancer statistics 1980: registrations. London: HMSO, 1983. (Series MBI No 12.)

${ }^{11}$ Dubrow R, Wegman DH. Setting priorities for occupational can- 
cer research and control: synthesis of the results of occupational disease surveillance studies. JNCI 1983;71:1123-42.

12 Williams RR, Stegens NL, Goldsmith JR. Associations of cancer site and type with occupation and industry from the third national cancer survey interview. JNCI 1977;59:1147-85.

${ }^{13}$ Kennaway EL, Kennaway NM. A further study of the incidence of cancer of the lung and larynx. Br J Cancer 1947;1:260-98.

${ }^{14}$ Pippard EC, Acheson ED, Winter PD. Mortality of tanners. Br J Ind Med 1985;42:285-7.

${ }^{15}$ Pippard EC, Acheson ED. The mortality of boot and shoe makers with special reference to cancer. Scand $J$ Work Environ Health (in press).

${ }^{16}$ Anderson JN. Applied dental materials. Oxford: Blackwell, 1967.

${ }^{17}$ Menck HR, Henderson BE. Occupational differences in rates of lung cancer. J Occup Med 1976;18:797-801.

${ }^{18}$ Lynge E. The Danish occupational cancer study. In: Prevention of occupational cancer. Geneva: International Labour Office, 1982.

${ }^{19}$ Coggon D, Pannett B, Acheson ED. Use of job-exposure matrix in occupational analysis of lung and bladder cancers on the basis of death certificates. JNCI 1984;72:61-5.

\section{Destruction of manuscripts}

From 1 July 1985 articles submitted for publication will not be returned. Authors whose papers are rejected will be advised of the decision and the manuscripts will be kept under security for three months to deal with any inquiries and then destroyed. 